\title{
FANCC Gene
}

National Cancer Institute

\section{Source}

National Cancer Institute. FANCC Gene. NCI Thesaurus. Code C86025.

This gene may play a role in DNA cross-link repair. 